\title{
DIE ONTW'ERP VAN 'N SENDINGBELEID IN DIE HUIDIGE SITUASIE
}

Sending is 'n deel van die vervulling van die apostoliese opdrag van die kerk. Dit geskied op grond van en in gehoorsaamheid aan Gods Woord. Teologiese besinning is daarom die eerste en grondliggende vereiste by die ontwerp van 'n sendingbeleid.

Hieroor wil ons hier egter nie handel nie. Die doel wat ons hier voor oë het, is om die bepalende faktore wat uit die huidige situasie spruit, in breë trekke in oënskou te neem. Die Evangelie word in die sendingwerk altyd in 'n definitiewe, konkrete situasie verkondig en daarom is dit van wesensbelang dat ons in die bepaling van 'n sendingbeleid hierdie situasie deeglik ken en daarmee rekening hou.

I Elke konkrete situasie is besonder en verskil van alle ander. So is die situasie in Afrika anders as in die Ooste, in die Unie anders as in Ghana, in Kaapland nog weer anders as in Transvaal. Tog kan ons belangrike, fundamentele beginsels en patrone onderskei wat gemeenkaplik aan almal is. 'n Sendingbeleid kan nie vir elke situasie apart bepaal word nie, maar moet op die gemeenskaplike, algemeen geldende beginsels gebou word. In ons ontwerp van'n sendingbeleid sal ons daarom op di gemeenskaplike en algemeen geldende moet let, terwyl ons die nodige rekbaarheid moet behou sodat die beginsels van ons sendingbeleid in elke afsonderlike situasie van toepassing gemaak kan word.

Met hierdie oorwegings in gedagte gaan ons daarom ook nie besondere aandag aan Afrika of die Unie of ons eie kerk bepaal nie, maar soek na grondliggende patrone wat in die huidige situasie te voorskyn tree. 'n Skrywer is egter ook altyd in 'n bepaalde situasie en daarom kan hy nie anders as om altyd met die een oog op sy eie situasie en die situasie van sy kerk te skryf nie.

Miskien die belangrikste les wat die werke van die groot Nederlander, Hendrik Kraemer, ons leer, is so vanselfsprekend dat dit dikwels by ons verbygaan sonder dat ons werklik erns daarmee maak: Ons het in die sending altyd met twee teenoor mekaar staande pole te doen. Aan die een kant staan die Bybelse Evangelie, aan die ander kant staan die heiden met sy ganse geestesinhoud, tradisie en geskiedenis. Aan die een kant staan Evangelie, aan die ander kant kultuur. Aan die een kant staan Kerk, aan die ander kant W'êreld. Aan die een kant Christus, aan die ander kant die sondaar. As ons met een van hierdie twee pole nie volle erns maak nie, het ons te doen met 'n fundamentele en prinsipiële vervalsing wat noodwendig op ons sendingwerk moet terugslaan.

Vanuit die huidige stand van sake gesien, was sulke fundamentele vervalsings kenmerkend van die Protestantse sending tot aan die begin van die twintigste eeu. Ten spyte van die feit dat waarskuwende stemme 
in die verlede nie ontbreek het nie en ten spyte van die feit dat die wêreldliteratuur op sendinggebied baie duidelik wys dat die vervalsings nog geensins iets van die verlede is nie, kan ons tog konstateer dat daar 'n besliste kentering in die teologiese besinni $\mathrm{g}$ oor sending sowel as die praktiese benadering van sendingwerk gedurende die afgelope paar dekades ingetree het. $\mathrm{Al}$ sou hierdie kentering nog nie volle werklikheid wees nie, het dit tog in der mate deurgewerk dat ons bewus van die probleme geword het en sendingprobleme in 'n nuwe lig kan bekyk. Hoewel gedagtes reeds sedert die Eerste Wêreldoorlog nuwe bane begin betree het, tree die kentering tog werklik eers sedert Tambaram 1938 te voorskyn. Dit is die werk van manne soos Hendrik Kraemer, maar dit kom ook grotendeels deur die veranderde wêreldsituasie. Miskien moet ons dit so stel: Die veranderde wêreldsituasie het ons gedwing om te luister na stemme waarna ons vroeër nie wou luister nie.

Die fundamentele vervalsing van die verlede kan die beste getipeer word onder die term sinkretisme: Die tipiese uitgangspunt was dié waar gemeenskaplike waarhede tussen die Christelike en heidense godsdienste gesoek word. Die Heidense godsdiens is 'n praeparatio etangelii, 'n soort „Ou Testament" wat die weg vir die Nuwe Testament baan. Om dit te kan regkry, moet die beskouing van die Bybelse waarheid baie rekbaar wees. Hierdie rekbaarheid word meesal gevind deur van die openbaring 'n soort fundamentele, algemene waarheid te maak. So word Christus dan nie meer die absoluut enige nie, maar ' $n$ tipe; ons kry ' $n$ genus Verlosser waarvan Christus die mees volmaakte, maar nog steeds net 'n spesifieke eksemplaar is. Die eph hapax van die openbaring in Christus is daarmee laat vaar. En sodra dit laat vaar is, is dit maklik om 'n soort eenheid te vind tussen heidense en Christelike godsdiens. Wat dan op die voorgrond kom, is nie die Verlosser Jesus Christus nie, maar menslike behoeftes, ideale, strewinge en religieuse ervaringe. Hiervandaan kom dan ook een van die bekende sendingsmetodes, $\mathrm{nl}$. „sharing religious experience".-Wat die praktiese resultate in die ,wen van siele" ook al mag wees, ons het hier nie meer met die suiwere Evangelie van die verlossing in een Naam Jesus Christus te doen nie.

Weliswaar het ons met bostaande die vrysinnige posisie geskets. Feit is egter dat baie ortodokse rigtings wat hulle toespits op die emosionele ervaring nie besef in watter geselskap hulle hulle bevind nie.

'n Ander tipe sinkretisme kry ons waar kultuur en Evangelie vermeng word. Uit hierdie gedagterigting spruit dan voort dat ons Westerse kultuur, of altans sekere gedeeltes daarvan, Christelik is, d.w.s. Bybels is en daarom absolute geldigheid besit. In die sendingwerk moet hierdie dele van die Westerse kultuur ook oorgedra word, want dit is as't ware deel van die Evangelie.-Dit is meesal die gedagte onder ortodokse groepe. In vrysinnige kringe word kultuur en Evangelie in der mate geïdentifiseer dat sendingwerk primêt 'n kulturele kwessie word-onderwys, landboumetodes, gesondheidsdiunste, verheffing van die lewensstandaard is van 
primêre belang; daarna sal die aanvaarding van die Christelike lewenswyse vanself volg of met geringe moeite aangeleer word.

Hierdie identifisering van Evangelie en Westerse kultuur sien ons baie duidelik in die nou verband tussen sendingwerk en staatsoptrede. In die verskillende kolonies het die Westerse kerke hulle sendingwerk meesal gedoen onder beskerming van die Europese koloniale mag en soms selfs militêre steun geniet. Dieselfde nou verband sien ons ook tussen sendingwerk en handelsbelange: Die sendingpos was dikwels ook handelspos en omgekeerd; en vir 'n lang tyd was sendingwerk in die Oos-Indiese gebied prakties een van die departemente van die Hollands-Oos-Indiese Kompanjie.

Die identifisering van Westerse kultuur en Evangelie kan ons ook sien in die reaksie van die heidense volke waaronder sending gedoen is. Oor die algemeen geld die Christelike godsdiens vir hulle as die godsdiens van die Weste. Aanvaarding van die Christendom beteken dan ook aanvaarding van Westerse gewoontes, wetenskap en tegniek. Christenwees beteken dan dikwels die Westerling se klere dra, sy taal praat, sy skole bywoon, sy huislike lewe na-aap en so meer. Dan verwag die nuwe Christen onwillekeurig ook om die Westerling se kundigheid, mag en welvaart daarmee saam te ontvang en ook om in die Westerse gemeenskap opgeneem te word.

Nog 'n tipe sinkretisme wat ek hier te berde wil bring, is die identifisering van Evangelie met 'n bepaalde kerk. Extra ecclesiam non salus en die kerk het 'n naam en adres. Hierdie beskouing is nie net Rooms nie, maar is ook deur Protestantse kerke oorgeneem. Die heeltemaal korrekte gedagte van die uiterste belangrikheid van kerk-vorming onder die bekeerde heidene neem dan die gestalte aan dat die kerk wat gevorm word net ' $n$ bepaalde kerk mag wees. Of die heidense bekeerling moet in die reeds bestaande, enigste reg-hebbende kerk opgeneem word, omdat geen ander kerk gevorm mag word nie (hoofsaaklik die Roomse gedagte), óf 'n soort Oosterse of Bantoe duplikaat van die Westerse kerk-volledig met kerkorde, liturgie en belydenis-moet gevorm word.

Sendingwerk met hierdie agtergrond en besiel met hierdie gees was moontlik tot enkele tientalle jare gelede. Dit het egter op twee veronderstellings berus: Eerstens is vanselfsprekend uitgegaan van die gelatenheid, passiviteit en selfs ondergeskiktheid van die heiden-volke. Tweedens is vanselfsprekend die teendeel hiervan aanvaar, naamlik die meerdere posisie van die Westerse volke en beskawing in alle opsigte, Solank die Westerse beskawing iets magtigs en verhewe is waarna opgesien moet word, kan 'n Westerse godsdiens en 'n Westerse kerk, wat deel van daardie verhewe Westerse beskawing en kultuur is, iets aantrekliks wees. Wanneer die Westerse beskawing egter nie meer hierdie verhewe posisie beklee nie, verander 'n Westerse godsdiens en kerk ook van status. 
Die Evangelie het dan sy hulptroepe verloor en moet alleen staan. En wanneer die Evangelie alleen staan, wanneer hy nakend is nadat sy pragtige tooisels afgeskeur is, het ons met 'n weerlose en nederige gestalte te doen - dieselfde nederige en weerlose gestalte van byna tweeduisend jaar gelede, maar 'n gestalte wat die belofte gehoor het: „Kyk, Ek is met julle al die dae tot aan die voleinding van die wêreld".

En dit is presies wat in die afgelope paar dekades geleidelik en soms ook skielik gebeur het.

Die ontwaking van die heidenvolke toon die volgende gemeenskaplike trekke:

(1) Dit is 'n ontwaking wat nie net nasionaal nie, maar ook nasionalisties gekleur is. M.a.w., die nasionale gevoel wat die ontwaking van die heidenvolke tipeer, is nie net 'n gesonde gevoel van samehorigheid, trots op die eie en begeerte om sigself te wees nie, maar daar is 'n sterk element van aggressiviteit, vyandigheid teenoor die vreemde en selfs gewelddadigheid. Dat dit 'n egte nasionale ontwaking is, kan ons egter nie betwyfel nie. Hoewel 'n land soos Japan reeds lankal 'n egte nasionalisme ontwikkel het, was die situasie in die grootste gedeelte van die Ooste en feitlik die hele Afrika só dat die inwoners verdeel was in 'n groot aantal stamme en gemeenskappe, terwyl die een stam dikwels vyandiger teenoor die ander stam gestaan het as teenoor die Westerlinge. 'n Gevoel van samehorigheid en solidariteit teenoor 'n gemeenskaplike vyand het nie bestaan nie. Tans is dit anders: Ten spyte van al die innerlike verskille wat so groot kan wees dat dit soms tot wapengeweld lei, het Indië, Pakistan, Indonesië en 'n hele aantal gebiede in Afrika (om 'n paar voorbeelde te noem) genoeg samehorigheidsgevoel ontwikkel om moderne state te vorm. In A frika het die oorweldigende antal Bantoe nog nie tot die vorming van eie selfstandige state gekom nie, maar ook hier vind ons groot nasionale leiers wat daarin slaag om die hele inboorling-bevolking, ten spyte van stamverskille, agter hulle te verenig. Selfs in die Unie verdwyn die verskille tussen Zulu en Xhosa, tussen Nguni en Sotho vinniger as wat 'n mens dink en groei die gedagte van die samehorigheid van alle Bantoe, omdat die Bantoe as geheel gemeenskaplike belange het. Daar is selfs 'n groeiende gevoel van solidariteit tussen al die nie-blanke inwoners van die vasteland van Afrika (met uitsondering-miskienvan die Asiate), sodat Ghana homself as kampvegter van die „onderdrukte” Afrika voel en die Bantoe in ons land na Ghana as 'n ideaal opsien.

(2) Hoewel hierdie ontwaking uit die volke self voortkom, kan ons die grondslag, aard en vorm daarvan met reg 'n Westerse uitvoer-produk noem. Feitlik sonder uitsondering is die leiers van hierdie nasionale bewegings kwekelinge van skole (meesal sendingskole) gestig deur Westerlinge en het hulle hulle verdere opleiding aan W'esterse universiteite geniet. Hulle het die Westerse wetenskap en tegniek, veral militêre tegniek, regeringstelsels, politieke metodes, ekonomie, onderwys, godsdiens-alles van naderby deeglik leer ken. Daarmee het die Weste hulle 
deur en deur gevorm om as leiers te kan optree. Op laer vlak het die Westerse volke in hulle koloniale gebiede werkers van allerlei aard nodig gehad. Dit is maar enkele gebiede van die wêreld (die suidelike deel van Afrika, Nu-Seeland, Australië en die Amerikas) wat werklik nedersettingsgebiede van die Weste geword het en so 'n bevolking van Westerse oorsprong gekry het en blykbaar sal hou. Die res van die wêreld was in werklikheid slegs handelsgebiede, veral gebiede waarvandaan grondstowwe verkry kon word. In hierdie gebiede veral is dankbare gebruik gemaak van inboorlinge as amptenare, soldate en alles wat nodig was. Dit het die Westerse volke betaal, maar het tegelykertyd die fondament van ' $n$ nasionale organisasie op alle terreine gelê.-Ook die nasionalisme self is 'n Westerse uitvoerproduk: Die vorming van 'n groot geheel (volk of nasie) wat soveel meer mag as kleiner, plaaslike groepe het; die handhawing van die regte van daardie geheel en die verkryging van allerlei voordele daarvoor; die sterk militêre tendens wat altyd op die agtergrond skuil; aktiviteit in plaas van passiviteit, dinamiek in plaas van 'n statiese toestand-al hierdie dinge is sedert die veertiende eeu tipies Westers en is op die nie-Westerse volke oorgedra.

(3) Die nasionale ontwaking van die heidenvolke het 'n sterk neiging tot Kommunisme. Hierdie neiging kom nie net uit die huidige wêreldsituasie, waar dit 'n baie voordelige posisie is om Amerika en Rusland teen mekaar te laat kompeteer in die gee van geskenke nie; dit kom ook nie net uit die anti-W'esterse gevoel, wat vriende met die yande van die W'este wil wees nie. Die kommunistiese tendens in die nasionale ontwaking van die heidenvolke het beslis ook te doene met die feit dat die kommunistiese sosiale struktuur in baie opsigte natuurliker by' 'n primitiewe of betreklik primitiewe gemeenskap aanpas. Die primitiewe gemeenskap met sy swak ontwikkelde sin vir privaatbesit gepaard met 'n sterk sin vir die gemeenskaplike eiendom van die stam of gemeenskap (stamgrond, jaggebied, waterregte en so meer), swak individualiteitsgevoel met ' $n$ sterk eenheidsgevoel met die stam of gemeenskap en verder die sterk gesag van die regerende persoon bring mee dat 'n aangepaste kommunistiese sisteem dikwels beter ingang kan vind as die Westerse demokratiese sisteme. Daarby moet ons onthou dat die heidenvolke vry is van die tradisionele simpatië en antipatië wat eie aan die Westerse volke is.

(4) Al die heidenvolke het groot waardering vir die materiële kultuur van die Weste. Die Westerse kundigheid met sy leuse van „,kennis is mag” is ' $\mathrm{n}$ middel tot verowering van die begeerde welvaarts- en magsmiddele. Die Westerse geestelike kultuur-kuns, sedelikheid, godsdiens, waardes en norme op alle gebiede-word egter verwerp en vervang met wat eie aan die betrokke volk is.

(5) Dwarsoor die wêreld bring hierdie ontwaking ook 'n reaksie teen die Christelike godsdiens mee. Die eng verbinding tussen Westerse kultuur en Christelike godsdiens-wat die skuld van die sendende organisasies en kerke is-laat 'n natuurlike reaksie ontstaan waardeur 
die Christelike godsdiens gesien word as die godsdiens van die Westerse volke. Die Christelike sending is daarom deel van die imperialisme en kolonialisme van die Weste; die Christelike godsdiens is vyandig teenoor die inheemse kultuur.-Hierin sit 'n baie groot mate van waarheid. Eerstens het ons Christelike geloof en Westerse kultuur te nou aan mekaar verbind. Tweedens het ons die sending te veel toegelaat om 'n onderdeel van koloniale administrasie en handel te word. Derdens is 'n volk se godsdiens altyd die grondslag waarop sy hele kultuur berus; godsdiens en kultuur is so eng verbind, so 'n geïntegreerde geheel, dat verandering van godsdiens 'n geestelike revolusie is wat die kultuur van 'n volk van solder tot kelder moet affekteer. Dit geld die Christelike godsdiens met sy absolute aansprake nog meer as enige ander godsdiens. En dit voel die heiden aan, al sou hy dit nie rasioneel besef nie. Wanneer die Westerse sending nou die fout maak om nie te besef dat die Evangelie bo alle kultuur verhewe is en nie van enige kultuur afhanklik is nie, dan volg dit logies dat die geestelike revolusie van die heidenvolk die kleur van 'n fundamentele ver-W'estersing moet aanneem. Die Evangelie bestaan nie los van enige kultuur nie-dit bestaan nie los van mense nie en mense is altyd deel van een of ander kultuur. Maar die Evangelie is nie verbonde aan 'n bepaalde kultuur nie en dwing ook nie alle kulture in dieselfde patroon in nie. 'n Oosters-Christelike kultuur sal daarom nog altyd iets totaal verskillend van 'n W'esters-Christelike kultuur wees. Maar dit het ons nie altyd besef nie en dit besef die heidenvolke dikwels ook nie. Daarom die anti-Christelike tendens wat ons meesal by die nasionale ontwaking van die heidenvolke vind. Trouens-ons moet verwag dat die hewigheid van reaksie teen die Christelike godsdiens die sterkste sal wees. Materiële kultuur-fabrieke, klere, voedsel, ens.-lê op die periferie van ons menslike bestaan. Die godsdiens is die ander uiterstedit is die kern van ons hele menssyn. Daarom sal die reaksie van die heiden baie minder hewig teen die materiële dinge wees en sal hy lg. selfs met gretigheid aanvaar, terwyl hy teen die Christelike godsdiens hewig in verset kom, omdat hy daarin die verandering van sy hele wese aanvoel. Daarom voel hy die Christelike godsdiens aan as kultuurvyandig en is die aanvaarding van die Christelike geloof gelyk te stel met verraad teenoor sy eie kultuur.

Teenoor die kragsontplooiing in die heidenwêreld staan 'n insinking van die Weste. Hier wil ek net 'n paar punte aanstip:

(1) Twee wêreldoorloë het die Weste sat en moeg van geweldpleging gemaak, sodat ' $n$ W'esterse volk wat sy posisie deur geweld handhaaf, die misnoeë van die hele Westerse wêreld moet verduur. Daarby kom nog dat die oorloë die Westerse lande ekonomies tot so 'n mate uitgeput het dat hulle duur militêre ondernemings nie meer kan bekostig nie.

(2) Dieselfde oorloë het die Weste agterdogtig teen nasionalisme gemaak-in so'n mate dat die woord "nasionalisme" in ons dae feitlik 
'n skelwoord geword het. Die nasionalisme van die heidenvolke wek daarom die misnoeë van die Westerse lande, maar die Weste kan nie met 'n ewe sterk of sterker nasionalisme antwoord nie.

(3) Die balans van magte is so dat die Weste nêrens eintlik kan optree nie. Die heidenvolke weet presies hoe om die een teen die ander uit te speel en het die waarde van propaganda leer besef.

(4) Teenoor die vroeëre oortuigdheid van die geldigheid van sy eie norme en waardes het die Weste die slagoffer van relativisme geword - ons waardes en norme, ons sedelikheid en godsdiens is ons s'n; ander mense het weer ander norme en beskouings wat hulle met ewe veel reg handhaaf as wat ons ons s'n handhaaf. Objektiewe, algemeen geldende waardes en waarhede bestaan nie meer nie. Die Weste is daarom dikwels in die posisie dat hy die beskouings van die ander erken, sonder dat sy beskouings erken word.

(5) Die Weste word besiel met 'n gees van culpa mea sodra hy met die ander volke te doen kry. Westerse lande is vandag maar te gereed om skuld te bely-ons het die primitiewe volke van die wêreld oorwin, uitgeroei, hulle grond afgeneem, hulle sedes verwoes, hulle rykdomme geroof net terwille van materiële voordeel. Ons het hulle niks in die plek daarvan gelaat nie-die rykdom het na die Weste gegaan en hulle het die verwoeste lande, die geestelike verwarring, die godsdienstige en sedelike verval, die brandewyn en basterkinders oorgehou. Ons het vir hulle Westerse gewoontes, skoling en godsdiens gegee, maar ten spyte van ons mooi praatjies geweier om hulle in die Westerse gemeenskap op te neem. En so kan ons aangaan. Hierdie slegte gewete is dan geneig om die Westerling te dwing om maar alles wat van die vroeëre koloniale gebiede se kant kom, te pamperlang.

(6) Tegelykertyd het die Weste in so'n mate die Christelike geloof kwytgeraak dat 'n hele aantal skrywers--van Rousseau in die 18de eeu, oor Feuerbaci en Nietzsche in die 19de eeu tot by Toynbee in ons eie dae-van ons tyd as die ,post-Christian era" wil praat. Die heidenvolke merk dit baie goed op en reageer met die gedagte dat die Christelike godsdiens tog eintlik maar net 'n uiterlike vorm en blote lippediens is. Aan die ander kant is die Christelike godsdiens nie vir die Westerse lande van soveel belang dat dit ernstige internasionale komplikasies regverdig nie.

Met hierdie dinge het die Weste in 'n swak posisie beland. Hierdie swakheid is nie soseer 'n militêre kwessie nie. Dit is 'n geestelike kwessie. Dit is die probleem wat ontstaan uit besluiteloosheid, onsekerheid, twyfel aan sigself, gebrek aan oortuiging en geloof, slegte gewete en verlore reputasie.

Daarmee val sterk meewerkende faktore vir die sending weg. Die status van die Christelike godsdiens het saam met die status van die Westerse volke en Westerlinge gedaal. Die mag van wapens is nie meer daar om die sendeling en sy volgelinge te beskerm nie. Die sendeling en 
die sendingkerk is uitgelewer aan vyandige magte, wat weet dat vergelding hulle nie sal agterhaal nie. Baie gebiede is eenvoudig van owerheidsweë vir die sending gesluit, terwyl inheemse Christene in menige opsig vervolging moet verduur. Nog meer as wat sending dit gewoonlik doen, word ons deur hierdie dinge herinner aan die posisie van die kerk en die Christene van die eerste drie eeue na Christus.

Wat die nuwe verwikkelinge vir die sending meebring, wil ons hier opsommend in 'n paar punte stel:

(1) Sedert die Eerste Wêreldoorlog het 'n kentering in ons teologiese denke gekom waardeur ons weereens opnuut onder die besef van die absolute geldigheid van die Bybelse Evangelie gekom het. Hierdie besef het in die missiologiese besinning deurgewerk en die druk van omstandighede het ons bereid gemaak om te luister. Daar is allerhande rigtinge en diskussies op hierdie gebied aan die gang, maar die belangrikste is die rigting wat staan onder leiding van Kraemer en sy talle navolgers wat die absoluutheid van die Evangelie in die sendingveld beklemtoon. Dit beteken dat die Evangelie nie vervals mag word deur dit op welke wyse ook al met die heidense godsdiens te vermeng of te verbind nie. Maar dit beteken ook dat die Evangelie nie met enige kultuurvorm geidentifiseer of daarvan afhanklik gemaak mag word nie. Die Evangelie is die grondslag wearvan die kultuur afhanklik is, die suurdeeg wat die hele kultuur deursuur, maar die Evangelie is nie van een of ander kultuurvorm afhanlkik nie. Die Westerse Christendom is daarom maar een van die moontlike gestaltes wat onder invloed van die Evangelie kan ontstaan; maar so kan daar talle ander gestaltes op grond van die Evangelie groei.

(2) Konsekwent deurgevoer bring hierdie gedagte die enorme teologiese taak met sig mee om in die Bybel te onderskei tussen Joodse, Griekse en Romeinse kultuur aan die een kant en Evangelie aan die ander kant; om in ons kerklike en teologiese denke en handeling tussen Westerse kultuur en Evangelie te onderskei. En uiteindelik moet ons insny in dinge wat vir ons van die allergrootste belang geword het: Ons dogmas en belydenisskrifte, wat wel Bybelse waarhede uitdruk, maar tog onder die druk van heel besondere omstandighede geformuleer is. Hierdie onderskeidinge is van die allergrootste belang vir die boodskap wat ons in die sendingveld gaan bring en vir wat ons daar gaan probeer opbou.

(3) Hierdie teologiese rigting, gepaard met die opkoms van die heidense volke en die agteruitgang van die Weste, bring 'n toegespitste belangstelling in die heidense kulture as sodanig met sig mee. Belangstelling in nie-Westerse volke en kulture en godsdienste was daar altyd in die Weste. Tydens die Middel-Eeue is daar al groot belangstelling in die Arabiere. Na die ontdekkingstogte van die Renaissance en vroeg-moderne tyd is daar geweldige belangstelling vir die nuwe volke wat binne die gesigskring van die Weste gekom het en tydens die Aufklärung is daar 
selfs bewondering vir die Sjinese kultuur. So sterk is hierdie belangstelling in die vreemde dat dit die Westerse denke belangrik beïnvloed het. Tog was die Westerling onbewus vanselfsprekend op die standpunt van die absolute geldigheid van sy eie norme, waardes en godsdienstige oortuigings. Sy kultuur was vanselfsprekend die hoogste. Die belangstelling in ander was daarom meer die prikkel van iets nuuts en die opregte vreugde en aangename verrassing om te vind dat ander ook 'n merkwaardige hoë peil van ontwikkeling bereik het--waar die maatstaf om die hoogte van ontwikkeling te meet weer die Westerse kultuur was. Terloops kan ons opmerk dat hierdie gees ook anleiding gee tot die feit dat Christelike sending in 'n groot mate ook politieke en kulturele sending was.-Die belangstelling van die afgelope paar dekades gaan gepaard met 'n groter nederigheid van die kant van die Weste. Die relativisme wat die W'este beetgepak het, het die heilsame invloed gehad dat die vreemde kulture as eenhede op sigself gesien en geken word, en nie meer bloot in hulle kontras en ooreenkoms met die Westerse kultuur nie. Die heidense kultuur is eiesoortig, met sy eie norme, beginsels, ideale, tradisie en geskiedenis. Die heidense godsdiens is nie iets minderwaardigs en valse duiwelswerk wat maar eenkant geskuif kan word nie, maar 'n geïntegreerde deel van die volk se kultuur en net so goed die voedingsbodem vir daardie kultuur as wat die Christelike godsdiens 'n voedingsbodem vir die Westerse kultuur was en is. Hierdie besef bring mee dat ons in ons sendingwerk ook groter eerbied vir die kultuur van die volk waaronder ons werk, moet hê. Ons moet die Evangelie bring en nie een of ander kultuur nie. Die Evangelie sal die hele kultuur van die heidenvolk omvorm, maar die gestalte wat daaruit voortkom, sal eie aan daardie volk wees. Hierdie gestalte moet geleidelik uitgroei namate die Evangelie ingeplant word en deurwerk. Maar hierdie nuwe gestalte kan nie deur ' $n$ W'esterling uitgedink word en dan op die betrokke volk afgedruk word nie; die volk sal self daardie gestalte moet vind en letterlik uitlewe, omdat kultuur iets is wat uit die siel van die volk gebore moet word.

(4) Hierdie erkenning van die heidenvolke se eie reg en eie strewe en eie kultuurvorme bring ook logies mee dat die Westerse kerke prinsipieel en prakties die noodsaaklikheid van die stigting van inheemse kerke moes erken. Die opkoms van die heidenvolke het die Westerse kerke ook dikwels daartoe gedwing, omdat die W'esterlinge uitgedruk is en daar net een manier was om die inheemse Christendom nie te laat ondergaan nie en dit was die vorming van 'n selfstandige inheemse kerk. PrinsipieelBybels het die sendende kerke ingesien dat daar geen regverdiging bestaan vir 'n situasie waar die inheemse kerk 'n afhanklike byvoegsel van die moederkerk, of die inheemse Christene ' $n$ minderwaardige aanhangsel van 'n Europeane-gemeente is nie. In die praktyk is hierdie aanhangsel of byvoegsel alty'd ondergeskik en minderwaardig, omdat die Europese Kerk of die Europeane-gemeente altyd ekonomies die sterkere is en omdat die ,nuwe Christene" psigologies altyd ondergeskik aan die ",ou Christene" voel. Al sou daar geen rasseskeiding wees nie, klasse- 
skeiding is daar tog altyd. Prakties blyk dit ook hier in Suid-Afrika dat die selfstandige Bantoekerk 'n groter ,werfkrag" het as 'n kerk wat 'n aanhangsel van 'n blanke kerk is.

Vir ons sendingbeleid bring dit enorme probleme mee: (i) Die teologiese probleem van die skepping van veelvuldige kerke; (ii) Die posisie van ampsdraers en lidmate van die moederkerk in die dogterkerk en omgekeerd; (iii) Die probleem van in hoeverre van inboorling-werkkragte gebruik gemaak moet word. Moet uitsluitlik inboorlinge gebruik word of ook Westerlinge? Indien van lg. gebruik gemaak word, wat is hulle posisie in die inheemse Kerk? (iv) Probleme van eiendomsreg en finansiële beheer; (v) Die probleem van die graad van selfstandigheid van die dogterkerk-volkome selfstandigheid waar die moederkerk alles aan die dogterkerk oordra, of vryheid binne sekere grense, waaruit dan onmiddellik die probleem ontstaan van waar hierdie grense getrek moet word; (vi) Die probleem van die formulering van 'n eie geloofsbelydenis, liturgie, kerkwet, dogma ens. deur die dogterkerk.-Ons volstaan hiermee.

(5) Die onafhanklikheid van die Evangelie moet nie net teenoor kulture en kerke geproklameer word nie, maar ook teenoor staat en handelsbelange. Die versoeking is geweldig groot om die steun van die staat te geniet of om deur een of ander geweldige onderneming gedra te word. Hierdie dinge is in die verlede gedoen, maar op so'n wyse dat sending grootliks afhanklik van die staat of handelsonderneming geword het en in die oë van die inboorling daarmee geïdentifiseer is. Daaruit het ons ons les geleer. Die sending kan nooit 'n weg volg wat van buite voorgeskrywe word nie. W'anneer 'n staat 'n beleid volg waarmee die sending akkoord kan gaan, is dit alleen rede tot dankbaarheid; maar die sendingbeleid word op ander as politieke en staatkundige gronde aanvaar en moet daarom selfstandig geformuleer en uitgewerk word. So'n houding vereis normaalweg groter offers van die sendende kerk sowel as van die sendeling wat homself dikwels aan die grootste ge are weerloos moet blootstel. Maar juis in hierdie blootstelling besef ons beter dat sending per slot van rekening die werk van die groot Sender is, van wie ons slegs die instrumente is.

(6) Dieselfde gevare bedreig ons missiologiese denke vandag as vroeër, hoewel dit ander vorms kan aanneem. Vroeër is ons sending baie sterk beinvloed deur Westerse ekonomiese belange, deur politieke rigtinge en situasies, deur kerklike belange, teologiese en filosofiese rigtinge en hierdie kragte bestaan vandag nog. Heeltemaal daarsonder kan ons nie klaarkom nie, maar ons moet al die geeste tot die uiterste toe beproef.

Waar ons vroeër beïnvloed is deur die gedagte van die meerderwaardigheid van die Weste, kan ons nou ewe goed deur 'n onmatige bewondering van ander kulture op 'n dwaalspoor gelei word.

Waar ons vroeër met Westerse imperialisme groot skade aangerig het, kan ons nou ewe swaar fouteer deur alle Westerse gesag en invloed prys te gee. 
Waar ons vroeër deur eie nasionalisme beweeg is om ons eie belang te soek, dikwels tot skade van ander volke, kan ons vandag net soveel sondig deur 'n sieklik-sentimentele gees wat alle nasionale onderskeidinge, eie trots en selfrespekte uitwis.

Waar rassevooroordele en rassetrots in die verlede baie skade angerig het, kan ons nog meer skade aanrig deur 'n onreali tiese beleid waar ons maak asof daar geen verskille tussen rasse bestaan nie.

Waar ons in die verlede te geneig was om inheemse Christene in 'n afhanklike en onderhorige posisie te hou, kan ons ewe goed dwaal deur nou eenvoudig alles aan hulle oor te gee.

Ten slotte: Ons leef in 'n oorgangstyd waar ou vorme vervaag en verdwyn en nuwe vorme nog nie behoorlik gestalte gekry het nie. Hierdie revolusionêre proses het nie net die wêreld en wêreldse dinge beet nie, maar ook die sending. Dikwels weet ons nie behoorlik waar ons is of waarheen ons gaan nie. Maar in alle onrus en onsekerheid is een ding onbetwyfelbaar seker: Die Here het aan Sy kerk die opdrag gegee om die Evangelie aan alle mense te bring en hierdie opdrag moet uitgevoer word. En as ons dikwels nie weet hoe om die opdrag uit te voer nie, het ons as gelowiges en as kerk net een rigsnoer: Die Bybel. As ons die Bybel verkondig, kan ons nie verkeerd gaan nie. Maar vandag meer as ooit het ons ernstige, fundamentele, nugtere Bybelse besinning nodig. Alleen langs hierdie weg sal ons die lig vind.

\section{P. S. Dreyer, D.Phil.}

